\title{
Analisis Rasio Profitabilitas, Solvabilitas dan Likuiditas Terhadap Harga Saham Perusahaan IDX30 Di Bursa Efek Indonesia
}

\author{
David Kelvincent ${ }^{1}$, Vargo Christian L. Tobing ${ }^{2}$ \\ Program Studi Akuntansi, Universitas Putera Batam, Indonesia \\ Email korespondensi: pb180810055@upbatam.ac.id
}

\begin{abstract}
This research was conducted to determine the effect of profitability, solvency and liquidity ratios on the stock price of IDX30 companies on the Indonesia Stock Exchange. The population in this study were 30 companies listed on the IDX30 index on the Indonesia Stock Exchange. The sampling technique used was purposive sampling and the sample in this study was 15 companies. The data used in this study is secondary data in the form of financial statements. The data is obtained from the Indonesia Stock Exchange website. The results of the t-test showed that the profitability ratio (Net Profit Margin) partially had no significant effect on stock prices, the solvency ratio (Debt Equity to Ratio) partially had no effect on stock prices and the liquidity ratio (Current Ratio) partially had no effect on prices. share. The results of the f test show that profitability (Net Profit Margin), solvency (Debt Equity to Ratio) and liquidity (Current Ratio) simultaneously have no effect on stock prices. In the results of the coefficient of determination, the percentage of the independent variable on the dependent variable is $7.1 \%$ and the difference is $92.9 \%$ influenced by other factors not examined in this study.
\end{abstract}

Keywords : Liquidity; Profitability; Solvency; Stock Price.

\section{PENDAHULUAN}

Seiring majunya perubahan dibidang teknologi yang amat pesat beberapa tahun belakangan memberikan kemudahan dalam berbagai aspek kehidupan. Hal ini tidak terkecuali pada pasar modal di Indonesia yang terus melakukan inovasi dengan memanfaatkan perkembangan teknologi yang semakin memudahkan para calon investor untuk melakukan investasi pada salah satu instrumen investasi yaitu saham. Penambahan jumlah investor yang terjadi juga harus diimbangi dengan pengetahuan yang baik salah satunya adalah risiko dari investasi saham. Selain memberikan keuntungan seperti capital gain dan dividen, investasi pada instrumen saham juga memilki risiko yang dapat mengakibatkan terjadinya kerugian yaitu capital loss yang disebabkan karena adanya fluktuasi harga saham. Oleh sebab itu, sebelum memutuskan untuk melakukan investasi pada saham, sebaiknya mengetahui profil risiko masing-masing terlebih dahulu agar dapat meminimalisir risiko yang akan terjadi.

Fluktuasi harga saham dapat terjadi karena terkena pengaruh dari berbagai macam faktor, seperti dari internal perusahaan berupa kebijakan yang dibuat oleh para manajemen perusahaan terkait dengan aksi korporasi dan proyeksi kinerja perusahaan di tahun mendatang, sedangkan faktor kedua yang bisa mempengaruhi fluktuasi dari harga saham yaitu dari luar perusahaan (eksternal) seperti pengaruh dari kebijakan pemerintah dan kondisi fundamental ekonomi makro. Harga saham dapat menjadi dasar penilaian terhadap kemampuan manajemen sebuah perusahaan dalam menjalankan kegiatan operasional perusahaan. Kinerja keuangan perusahaan yang positif bisa membuat saham perusahaan mulai diminati dan dilirik oleh banyak investor sebagai tujuan investasinya. Dengan banyaknya minat dari investor, maka terjadi kenaikan permintaan (demand) terhadap saham perusahaan yang mengakibatkan harga saham mengalami kenaikan. Analisis kinerja keuangan sebuah entitas bisa digunakan dengan menganalisis rasio keuangan yang ada seperti, profitabilitas (profitability), solvabilitas 
(solvency), dan juga likuiditas (liquidity). Rasio keuangan dapat mencerminkan kinerja atau performa keuangan dari suatu emiten selama beberapa tahun terakhir yang dapat diperbandingkan sehingga para investor mampu menilai apakah performa perusahaan mengalami peningkatan atau penurunan yang dapat mempengaruhi keputusan mereka untuk melakukan investasi pada suatu perusahaan.

Rasio profitabilitas digunakan untuk mengetahui keahlian perusahaan dalam mendapatkan keuntungan dengan memakai margin laba kotor ataupun bisa disebut dengan Gross Profit Margin, margin laba bersih ataupun bisa disebut dengan Net Profit Margin, tingkat pengembalian atas aktiva atau biasa disebut dengan Return On Asset, dan tingkat pengembalian atas ekuitas bisa disebut juga sebagai Return On Equity. Semakin bertambah tingginya profitabilitas maka menandakan bahwa semakin bertambah tinggi juga tingkat keuntungan (laba) perusahaan. Tingkat Profitabilitas (laba) yang baik atau tinggi dapat menarik perhatian investor karena laba bersih per saham juga akan mengalami kenaikan.

Rasio solvabilitas ialah rasio yang digunakan dengan tujuan untuk mengetahui besarnya komposisi utang yang dipakai perusahaan di dalam melaksanakan operasional perusahaan. Perusahaan yang tidak solvabel merupakan perusahaan yang memiliki tingkat utang melebihi total aset yang dimiliki perusahaan. Jika semakin tinggi rasio solvabilitas, maka dapat berpengaruh pada tingkat profitabilitas karena ketergantungan permodalan perusahaan dari pihak luar seperti utang bank semakin besar sehingga beban bunga yang harus dibayar menjadi lebih besar dan mengurangi laba perusahaan. Hal ini dapat mempengaruhi harga saham perusahan mengalami penurunan dikarenakan kondisi fundamental perusahaan yang kurang baik dan tidak menarik minat investor. Rasio solvabilitas dapat dihitung dengan menggunakan rasio utang atas aktiva atau sering disebut Debt to Asset Ratio serta Debt to Equity Ratio atau juga bisa disebut sebagai rasio utang atas ekuitas.

Rasio likuiditas digunakan untuk mengetahui tingkat kemampuan entitas terkait untuk membayar utang jangka pendek. Perusahaan yang likuid adalah perusahaan yang memiliki total aset lancar lebih besar dari total kewajiban lancar (jangka pendek). Rasio likuiditas perusahaan yang tinggi menunjukkan semakin baik kinerja perusahaan dalam melunasi utang jangka pendek dengan menggunakan aset lancar perusahaan. Oleh harena itu, manajemen perusahaan harus meminimalkan tingkat utang yang dimiliki karena tingkat utang yang tinggi dapat berpengaruh pada harga saham.(Tobing \& Sitinjak, 2020) Jika tingkat utang rendah, hal ini dapat mendapatkan kepercayaan dari investor yang berpengaruh pada harga saham mengalami kenaikan. Rasio likuiditas bisa dihitung dengan rasio lancar atau disebut juga dengan Current Ratio, kemudian rasio cepat atau bisa disebut dengan Quick Ratio, serta rasio kas atau disebut juga dengan Cash Ratio.

Rumusan masalah dalam penelitian ini adalah sebagai berikut.

1. Apakah profitabilitas (NPM) memiliki pengaruh dalam memengaruhi harga saham perusahaan IDX30 di Bursa Efek Indonesia?

2. Apakah solvabilitas (DER) memiliki pengaruh dalam memengaruhi harga saham perusahaan IDX30 di Bursa Efek Indonesia?

3. Apakah likuiditas (CR) memiliki pengaruh dalam memengaruhi harga saham perusahaan IDX30 di Bursa Efek Indonesia?

4. Apakah profitabilitas (NPM), solvabilitas (DER), dan likuiditas (CR) secara simultan memiliki pengaruh dalam memengaruhi harga saham perusahaan IDX30 di Bursa Efek Indonesia? 


\section{KAJIAN TEORI}

\section{Profitabilitas}

Menurut (Hartono, 2017), rasio profitabilitas ialah rasio keuangan yang menilai kemampuan sebuah perusahaan dalam memperoleh keuntungan pada suatu periode akuntansi tertentu. Rasio profitabilitas bisa juga disebut sebagai rasio rentabilitas. Net Profit Margin merupakan rasio profitabilitas yang dipergunakan dengan tujuan menilai tingkat kemampuan entias dalam memperoleh keuntungan bersih dari tingkat penjualan perusahaan dalam suatu periode. (Sanjaya \& Rizky, 2018) Istilah lain dari Net Profit Margin adalah margin laba bersih. Tingginya tingkat margin laba bersih mengindikasikan bahwa laba bersih yang diperoleh perusahaan atas penjualan bersih tinggi. Hal ini dikarenakan laba sebelum pajak penghasilan yang tinggi. Sebaliknya, jika laba sebelum pajak penghasilan rendah maka akan mengakibatkan turunnya laba bersih dan menurunnya tingkat margin laba bersih. Net Profit Margin dapat dihitung dengan rumus berikut.

$$
N P M=\frac{\text { Laba Bersih Setelah Pajak }}{\text { Penjualan Bersih }} \times 100 \%
$$

\section{Solvabilitas}

Rasio solvabilitas ialah rasio keuangan yang dipakai dalam menakar tingkat kemampuan sebuah perusahaan dalam memenuhi utang perusahaan dalam jangka panjang baik dalam kondisi perusahaan masih beroperasi atau pada saat perusahaan dilikuidasi. (Mahulae, 2020). Debt to Equity Ratio yakni rasio yang dipakai dengan tujuan mengetahui tingkat utang perusahaan terhadap ekuitas perusahaan yang tersedia dalam sebuah perusahaan. (Cahyanti, Nuraina, \& Wijaya, 2017) Isitilah lain dari Debt to Equity Ratio adalah rasio utang terhadap modal. Rasio utang terhadap modal digunakan untuk melihat perbandingan komposisi dana untuk modal dari pihak kreditor dan pemilik. Rasio ini juga digunakan oleh pihak kreditor untuk menilai kelayakan kredit untuk debitur. Debt to Equity Ratio dapat dihitung dengan rumus berikut.

$$
\text { DER }=\frac{\text { Total Utang }}{\text { Ekuitas }} \times 100 \%
$$

\section{Likuiditas}

Rasio likuiditas yakni rasio keuangan yang dipakai oleh pihak-pihak pemakai laporan keuangan (baik pihak dari dalam maupun dari luar perusahaan) yang bertujuan untuk melihat tingkat kemampuan entitas dalam melunasi utang atau kewajiban dalam periode jangka pendek (kurang dari satu tahun). (Tiaras \& Wijaya, 2017). Current Ratio yakni rasio likuiditas yang dapat digunakan dengan tujuan untuk memberikan informasi mengenai tingkat kemampuan sebuah entitas dalam melunasi utang atau kewajiban dalam periode jangka pendek dengan akvita yang dimiliki. (Saputra \& Syarfan, 2017) Current Ratio dapat dihitung dengan rumus berikut.

$$
C R=\frac{\text { Aktiva Lancar }}{\text { Utang Lancar }} \times 100 \%
$$

\section{Harga Saham}

Permintaan dan penawaran bisa memegaruhi harga saham karena disebabkan oleh kinerja keuangan perusahaan dan juga sentimen-sentimen terkait perusahaan. Jika kinerja keuangan perusahaan baik dan memiliki sentimen yang positif, maka hal ini akan mendapat umpan balik yang baik ataupun juga mendapat respon positif oleh pasar dan investor sehingga mengakibatkan terjadinya peningkatan permintaan dan harga saham mengalami kenaikan. 


\section{Kerangka Pemikiran}

Kerangka pemikiran dalam penelitian ini adalah sebagai berikut.

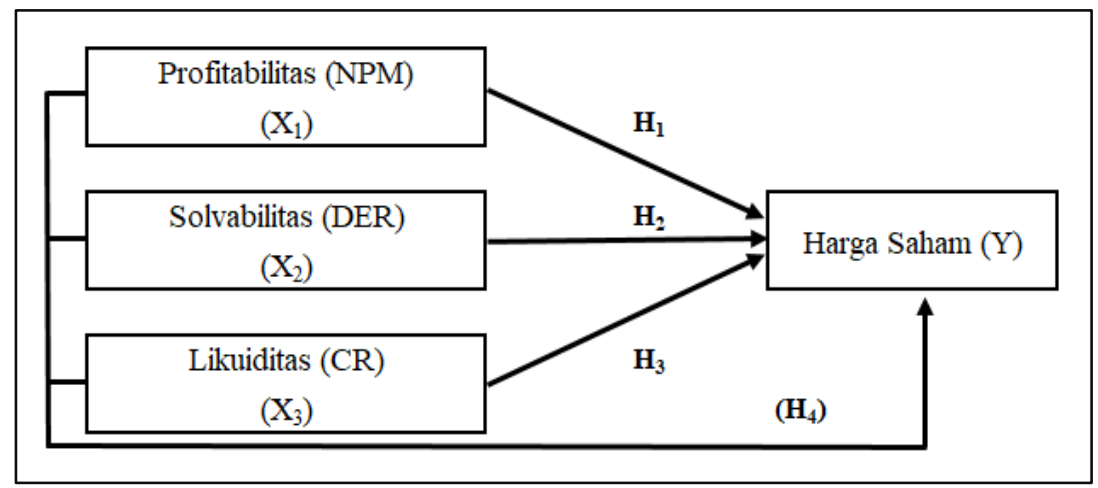

Gambar 1. Kerangka Pemikiran

(Sumber : Data Penelitian, 2021)

\section{Hipotesis Penelitian}

Hipotesis dalam penelitian ini adalah sebagai berikut.

H1 : Profitabilitas (Net Profit Margin) memengaruhi harga saham secara signifikan pada perusahaan IDX30 di Bursa Efek Indonesia.

H2 : Solvabilitas (Debt to Equity Ratio) memengaruhi harga saham secara signifikan pada perusahaan IDX30 di Bursa Efek Indonesia.

H3 : Likuiditas (Current Ratio) memengaruhi harga saham secara signifikan pada perusahaan IDX30 di Bursa Efek Indonesia.

H4 : Profitabilitas (Net Profit Margin), Solvabilitas (Debt to Equity Ratio), Likuiditas (Current Ratio) secara simultan memengaruhi harga saham secara signifikan pada perusahaan IDX30 di Bursa Efek Indonesia.

\section{METODE PENELITIAN}

Peneliti dalam melakukan penelitian memakai metode penelitian kuantitatif yang berasaskan prinsip positivisme. Sedangan rumusan masalah yang dipakai oleh peneliti ialah rumusan masalah asosiatif dalam melakukan penelitian ini karena bertujuan guna mengetahui pengaruh antara dua variabel atau lebih. (Tewal \& Jan, 2017). Populasi dalam penelitian ini merupakan perusahaan yang sudah go public dan yang terdaftar dalam indeks IDX30 pada tahun 20162020 yaitu sejumlah 30 perusahaan. Sampel dalam penelitian ini diambil dengan menggunakan metode purposive sampling. Berikut merupakan syarat-syarat yang ditentukan oleh peneliti, antara lain :

1. Perusahaan harus terdaftar (listing) pada indeks IDX30.

2. Data variabel yang dibutuhkan dalam penelitian tersedia.

3. Perusahaan harus terdaftar (listing) selama periode 2016-2020 dan tidak mengalami delisting.

4. Perusahaan memiliki laporan keuangan selama periode 2016-2020.

5. Perusahaam tidak mengalami kerugian selama periode 2016-2020. 


\section{HASIL DAN PEMBAHASAN}

\section{Uji Statistik Deskriptif}

Tabel 1. Hasil Uji Statistik Deskriptif

\begin{tabular}{|l|r|r|r|r|r|}
\hline & N & Minimum & Maximum & \multicolumn{1}{|c|}{ Mean } & \multicolumn{1}{|c|}{ Std. Deviation } \\
\hline NPM & 50 & 6.00 & 32.00 & 16.8200 & 7.91972 \\
\hline DER & 50 & 45.00 & 661.00 & 244.0200 & 223.72774 \\
\hline CR & 50 & 61.00 & 256.00 & 137.4000 & 50.76959 \\
\hline Harga Saham & 50 & 1215.00 & 12425.00 & 6835.3500 & 2984.08252 \\
\hline Valid N (listwise) & 50 & & & & \\
\hline
\end{tabular}

(Sumber : Hasil pengolahan data SPSS 25, 2021)

\section{Uji Normalitas}

\begin{tabular}{|l|r|r|}
\hline \multicolumn{4}{|c|}{ Tabel 2. Hasil Uji Kolmogorov Smirnov } \\
\hline $\mathrm{N}$ & & Unstandardized Residual \\
\hline Normal Parameters & Mean & 50 \\
\hline \multirow{2}{*}{ Most Extreme Differences } & Std. Deviation & .0000000 \\
& Absolute & 2875.52359230 \\
\cline { 2 - 3 } & Positive & .079 \\
\hline Test Statistic & Negative & .053 \\
\hline Asymp. Sig. (2-tailed) & & -.079 \\
\hline
\end{tabular}

(Sumber : Hasil pengolahan data SPSS 25, 2021)

Dari tabel di atas menunjukkan bahwa data sudah terdistribusi dengan normal karena nilai Asymp. Sig. (2-tailed) sebesar 0,200 telah melebihi dari nilai 0,05.

\section{Uji Multikolinearitas}

Tabel 3. Hasil Uji Multikolinearitas

\begin{tabular}{|l|l|r|r|}
\hline \multirow{2}{*}{ Model } & \multicolumn{2}{c|}{ Collinearity Statistics } \\
\cline { 2 - 4 } & NPM & Tolerance & VIF \\
\cline { 2 - 4 } & DER & .564 & 1.773 \\
\hline & CR & .556 & 1.798 \\
\hline \multirow{2}{*}{} & & .860 & 1.162 \\
\hline
\end{tabular}

(Sumber : Hasil pengolahan data SPSS 25, 2021)

Dari tabel diatas menunjukkan bahwa nilai VIF dari variabel Net Profit Margin (NPM) sebesar 1,773, Debt to Equity Ratio (DER) sebesar 1,798, dan Current Ratio (CR) sebesar 1,162 lebih kecil dari 10. Nilai tolerance dari variabel Net Profit Margin (NPM) sebesar 0,564, Debt to Equity Ratio (DER) sebesar 0,556, dan Current Ratio (CR) sebesar 0,860 telah melebihi dari 0,1 . Dengan demikian, dapat disimpulkan bahwa dalam penelitian ini tidak terjadi multikolinearitas karena nilai tolerance setiap variabel lebih besar dari 0,10 dan nilai VIF dari setiap vatiabel lebih kecil dari 10. 


\section{Uji Heteroskedastisitas}

Tabel 4. Hasil Uji Glejser

\begin{tabular}{|c|c|c|c|c|c|c|}
\hline \multicolumn{2}{|c|}{ Model } & \multicolumn{2}{|c|}{ Unstandardized Coefficients } & \multirow{2}{*}{$\begin{array}{c}\text { Standardized } \\
\text { Coefficients } \\
\text { Beta }\end{array}$} & \multirow[t]{2}{*}{$\mathrm{t}$} & \multirow[t]{2}{*}{ Sig. } \\
\hline & & B & Std. Error & & & \\
\hline \multirow[t]{4}{*}{1} & (Constant) & 750.784 & 296.095 & & 2.536 & .015 \\
\hline & NPM & -18.721 & 11.544 & -.307 & -1.622 & .112 \\
\hline & DER & .205 & 411 & .095 & .499 & 620 \\
\hline & $\mathrm{CR}$ & .343 & 1.458 & .036 & .235 & .815 \\
\hline
\end{tabular}

(Sumber : Hasil pengolahan data SPSS 25, 2021)

Dari tabel diatas, dapat disimpulkan pada penelitian ini tidak terdapat gejala heteroskedastisitas karena nilai signifikansi dari masing-masing variabel lebih besar dari 0,05 yaitu Net Profit Margin (NPM) sebesar 0,112, Debt to Equity Ratio (DER) sebesar 0,620, dan Current Ratio (CR) sebesar 0,815.

\section{Uji Auto Korelasi}

Tabel 5. Hasil Uji Auto Korelasi

\begin{tabular}{|c|c|c|c|c|c|}
\hline Model & $\mathrm{R}$ & R Square & $\begin{array}{l}\text { Adjusted R } \\
\text { Square }\end{array}$ & $\begin{array}{l}\text { Std. Error of the } \\
\text { Estimate }\end{array}$ & Durbin-Watson \\
\hline 1 & $.267^{\mathrm{a}}$ & .071 & .011 & 2967.80976 & .588 \\
\hline
\end{tabular}

(Sumber : Hasil pengolahan data SPSS 25, 2021)

Nilai pada uji Durbin-Watson sebesar 0,588 maka dapat dinyatakan bahwa terjadi fenomena autokorelasi karena tidak melebih dari nilai dU yaitu sebesar 1,6739. Sehingga untuk menghindari dari autokorelasi, dilakukan uji Cochrane Orcutt.

Tabel 6. Hasil Uji Auto Korelasi (Cochrane Orcutt)

\begin{tabular}{|l|r|r|r|r|r|}
\hline Model & R & R Square & \multicolumn{1}{c|}{$\begin{array}{c}\text { Adjusted R } \\
\text { Square }\end{array}$} & $\begin{array}{c}\text { Std. Error of the } \\
\text { Estimate }\end{array}$ & Durbin-Watson \\
\hline 1 & $.262^{\mathrm{a}}$ & .069 & .007 & 2010.97577 & 1.761 \\
\hline
\end{tabular}

(Sumber : Hasil pengolahan data SPSS 25, 2021)

Nilai pada uji Cochrane Orcutt menunjukkan nilai Durbin-Watson sebesar 1,761 dan dapat disimpulkan tidak terjadi autokorelasi karena telah telah memenuhi asumsi autokorelasi dU $<$ DW $<4-$ dU yaitu $1,6739<1,761<2,3261$.

\section{Analisis Regresi Linear Berganda}

Tabel 7. Hasil Analisis Regresi Linear Berganda

\begin{tabular}{|c|c|c|c|c|c|c|}
\hline \multicolumn{2}{|c|}{ Model } & \multicolumn{2}{|c|}{ Unstandardized Coefficients } & $\begin{array}{c}\text { Standardized } \\
\text { Coefficients } \\
\text { Beta }\end{array}$ & $\mathrm{t}$ & Sig. \\
\hline \multirow{4}{*}{1} & (Constant) & 9250.609 & 1828.579 & & 5.059 & 000 \\
\hline & NPM & -119.587 & 71.291 & -.317 & -1.677 & .100 \\
\hline & DER & .864 & 2.541 & .065 & .340 & .735 \\
\hline & CR & -4.474 & 9.003 & -.076 & -.497 & .622 \\
\hline
\end{tabular}

(Sumber : Hasil pengolahan data SPSS 25, 2021)

Berdasarkan tabel di atas dapat didapatkan persamaan dari regresi berganda berikut ini.

$$
\mathrm{Y}=9.250,609-119,587 \mathrm{X} 1+0,864 \mathrm{X} 2-4,474 \mathrm{X} 3
$$


Berdasarkan persamaan di atas dapat ditafsirkan sebagai berikut.

1. Nilai konstanta sebesar 9.250,609 berarti jika Net Profit Margin (X1), Debt to Equity Ratio (X2), dan Current Ratio (X3) memperoleh angka 0 maka nilai dari harga saham (Y) adalah 9.250,609.

2. Variabel Net Profit Margin (X1) mempunyai nilai koefisien sebesar -119,587 dan memiliki pengaruh negatif terhadap harga saham. Jika Net Profit Margin mengalami penurunan sebesar $1 \%$ maka harga saham akan mengalami penurunan sebesar 119,587

3. Variabel Debt to Equity Ratio (X2) mempunyai nilai koefisien sebesar 0,864 dan memiliki pengaruh positif terhadap harga saham. Jika Debt to Equity Ratio mengalami kenaikan sebesar $1 \%$ maka harga saham akan mengalami kenaikan sebesar 0,864 .

4. Variabel Current Ratio mempunyai nilai koefisien sebesar $-4,474$ dan memiliki pengaruh negatif terhadap harga saham. Jika Current Ratio mengalami penurunan sebesar $1 \%$ maka harga saham akan mengalami penurunan sebesar 4,474.

\section{Uji t (Parsial)}

Tabel 8. Hasil Uji t

\begin{tabular}{|c|c|c|c|c|c|c|}
\hline \multirow{2}{*}{\multicolumn{2}{|c|}{ Model }} & \multicolumn{2}{|c|}{$\begin{array}{l}\text { Unstandardized } \\
\text { Coefficients }\end{array}$} & \multirow{3}{*}{$\begin{array}{l}\text { Standardized } \\
\text { Coefficients } \\
\text { Beta }\end{array}$} & \multirow[t]{2}{*}{$\mathrm{t}$} & \multirow[t]{2}{*}{ Sig. } \\
\hline & & B & Std. Error & & & \\
\hline \multirow[t]{4}{*}{1} & (Constant) & 9250.609 & 1828.579 & & 5.059 & .000 \\
\hline & NPM & -119.587 & 71.291 & -.317 & -1.677 & .100 \\
\hline & DER & .864 & 2.541 & .065 & .340 & .735 \\
\hline & $\mathrm{CR}$ & -4.474 & 9.003 & -.076 & -.497 & .622 \\
\hline
\end{tabular}

(Sumber : Hasil pengolahan data SPSS 25, 2021)

Berdasarkan tabel di atas, dapat dilihat bahwa Net Profit Margin (X1) memiliki nilai signifikansi sebesar 0,100 > 0,05 sehingga dapat dinyatakan bahwa Net Profit Margin tidak berpengaruh signifikan terhadap harga saham. Sedangkan berdasarkan nilai $\mathrm{T}_{\text {hitung }}$ sebesar 1,677 dan $\mathrm{T}_{\text {tabel }}$ sebesar 2,01290, sehingga $\mathrm{T}_{\text {hitung }}<\mathrm{T}_{\text {tabel }}$ maka dapat disimpulkan bahwa Net Profit Margin tidak berpengaruh signifikan terhadap harga saham. Debt to Equity Ratio (X2) memiliki nilai signifikansi sebesar 0,735 >0,05 sehingga dapat dinyatakan bahwa Debt to Equity Ratio tidak berpengaruh signifikan terhadap harga saham. Sedangkakn berdasarkan nilai $\mathrm{T}_{\text {hitung }}$ sebesar 0,340 dan $\mathrm{T}_{\text {tabel }}$ sebesar 2,01290, sehingga $\mathrm{T}_{\text {hitung }}<\mathrm{T}_{\text {tabel }}$ maka dapat disimpulkan bahwa Debt to Equity Ratio tidak berpengaruh signifikan terhadap harga saham. Current Ratio (X3) memiliki nilai signifikansi sebesar 0,622>0,05 sehingga dapat dinyatakan bahwa Current Ratio tidak berpengaruh signifikan terhadap harga saham. Sedangkan berdasarkan nilai $T_{\text {hitung }}$ sebesar -0,497 dan $T_{\text {tabel }}$ sebesar 2,01290, sehingga $T_{\text {hitung }}<T_{\text {tabel }}$ maka dapat disimpulkan bahwa Current Ratio tidak berpengaruh signifikan terhadap harga saham. 


\section{Uji F (Simultan)}

Tabel 9. Hasil Uji F

\begin{tabular}{|l|l|r|r|r|r|r|}
\hline \multicolumn{2}{|l|}{ Model } & Sum of Squares & df & Mean Square & \multicolumn{1}{c|}{ F } & Sig. \\
\hline \multirow{2}{*}{1} & Regression & 31169514.563 & 3 & 10389838.188 & 1.180 & $.328^{\mathrm{b}}$ \\
\cline { 2 - 8 } & Residual & 405163160.562 & 46 & 8807894.795 & & \\
\hline & Total & 436332675.125 & 49 & & & \\
\hline
\end{tabular}

(Sumber : Hasil pengolahan data SPSS 25, 2021).

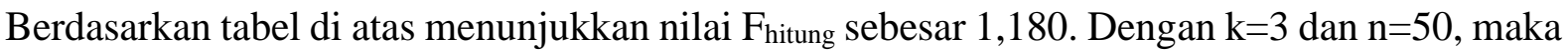
$\mathrm{F}_{\text {tabel }}(\mathrm{k} ; \mathrm{n}-\mathrm{k})$ yaitu $\mathrm{F}_{\text {tabel }}(3 ; 47)$ adalah sebesar 2,80 . Dengan demikian dapat disimpulkan bahwa NPM, DER, dan CR secara simultan tidak berpengaruh signifikan terhadap harga saham karena nilai $F_{\text {hitung }}$ sebesar 1,180 lebih kecil dari nilai $F_{\text {tabel }}$ sebesar 2,80 serta nilai signifikansi 0,328 lebih besar dari 0,05 yang mengartikan bahwa variabel NPM, DER, dan CR secara simultan tidak berpengaruh terhadap harga saham.

\section{Uji Determinasi $\left(\mathbf{R}^{2}\right)$}

Tabel 10. Hasil Uji Determinasi

\begin{tabular}{|l|l|r|r|r|}
\hline Model & R & R Square & $\begin{array}{c}\text { Adjusted R } \\
\text { Square }\end{array}$ & \multicolumn{1}{|c|}{$\begin{array}{c}\text { Std. Error of the } \\
\text { Estimate }\end{array}$} \\
\hline 1 & $.267^{\mathrm{a}}$ & .071 & .011 & 2967.80976 \\
\hline
\end{tabular}

(Sumber : Hasil pengolahan data SPSS 25, 2021)

Tabel di atas merupakan hasil uji derterminasi dan didapatkan nilai $\mathrm{R}^{2}$ sebesar 0,071 atau sama dengan $7,1 \%$. Hal ini dapat disimpulkan bahwa variabel NPM (X1), DER (X2), dan CR (X3) mempengaruhi harga saham (Y) sebesar 7,1\% dan sisanya sebesar 92,9\% dipengaruhi oleh variabel lain yang tidak diteliti.

\section{PEMBAHASAN}

\section{Profitabilitas tidak berpengaruh terhadap harga saham perusahaan IDX30 di Bursa Efek Indonesia}

Net Profit Margin (X1) memiliki nilai signifikansi sebesar 0,100 > 0,05 sehingga dapat dinyatakan bahwa NPM tidak berpengaruh signifikan terhadap harga saham. Sedangkan berdasarkan nilai $T_{\text {hitung }}$ sebesar -1,677 dan $T_{\text {tabel }}$ sebesar 2,01290, sehingga $T_{\text {hitung }}<\mathrm{T}_{\text {tabel }}$ maka dapat disimpulkan bahwa NPM tidak berpengaruh terhadap harga saham.

Profitabilitas merupakan rasio keuangan yang digunakan untuk mengukur tingkat kemampuan manajemen sebuah perusahaan dalam memperoleh keuntungan. Jika semakin tinggi tingkat profitabilitas menunjukkan pada semakin efektif sebuah perusahaan dalam memperoleh keuntungan, namun jika dilihat dari laporan keuangan perusahaan dalam 5 tahun terakhir mengalami fluktuasi dan nilai Net Profit Margin mengalami penurunan. Hal ini menandakan bahwa keuntungan yang diperoleh perusahaan mengalami penurunan sehingga tidak menarik minat investor ataupun calon investor untuk membeli saham perusahaan tersebut sehingga tidak berdampak pada kenaikan harga saham. 
Solvabilitas tidak berpengaruh terhadap harga saham perusahaan IDX30 di Bursa Efek Indonesia

Debt to Equity Ratio (X2) memiliki nilai signifikansi sebesar 0,735 > 0,05 sehingga dapat dinyatakan bahwa DER tidak berpengaruh signifikan terhadap harga saham. Sedangkakn

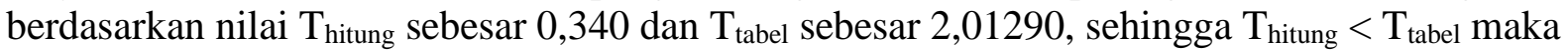
dapat disimpulkan bahwa DER tidak berpengaruh terhadap harga saham.

Solvabilitas adalah rasio keuangan yang digunakan untuk mengetahui seberapa besar tingkat modal sendiri dalam menjamin semua kewajiban yang dimiliki oleh perusahaan. Jika semakin tinggi rasio solvabilitas menandakan bahwa semakin tinggi risiko yang dimiliki oleh perusahaan karena harus membayar bunga utang yang semakin tinggi. Jika dilihat dari laporan keuangan perusahaan selama 5 tahun terakhir, nilai solvabilitas mengalami fluktuasi dan nilai Debt to Equity Ratio mengalami kenaikan. Kenaikan ini berpengaruh pada kurangnya minat investor dan calon investor untuk melakukan pembelian saham perusahaan sehingga tidak berdampak pada kenaikan harga saham.

\section{Likuiditas tidak berpengaruh terhadap harga saham perusahaan IDX30 di Bursa Efek Indonesia}

Current Ratio (X3) memiliki nilai signifikansi sebesar 0,622>0,05 sehingga dapat dinyatakan bahwa CR tidak berpengaruh signifikan terhadap harga saham. Sedangkan berdasarkan nilai $\mathrm{T}_{\text {hitung }}$ sebesar $-0,497$ dan $\mathrm{T}_{\text {tabel }}$ sebesar 2,01290, sehingga $\mathrm{T}_{\text {hitung }}<\mathrm{T}_{\text {tabel }}$ maka dapat disimpulkan bahwa CR tidak berpengaruh terhadap harga saham.

Likuiditas adalah rasio keuangan yang digunakan untuk mengetahui tingkat kemampuan perusahaan untuk memenuhi kewajiban jangka pendek yang sudah jatuh tempo. Jika semakin tinggi rasio likuiditas sebuah perusahaan menandakan bahwa perusahaan mampu memenuhi kewajiban jangka pendek dan dapat disebut bahwa perusahaan tersebut adalah perusahaan yang likuid. Jika dilihat dari laporan keuangan selama 5 tahun terakhir, nilai likuidias mengalami fluktuasi dan nilai Current Ratio mengalami penurunan. Penurunan ini menandakan bahwa kemampuan perusahaan untuk membayar kewajiban jangka pendek mengalami penurunan sehingga para investor dan calon invetor tidak tertarik untuk melakukan pembelian saham perusahaan sehingga tidak berdampak pada kenaikan harga saham.

\section{Profitabilitas, Solvabilitas dan Likuiditas secara simultan tidak berpengaruh terhadap harga saham perusahaan IDX30 di Bursa Efek Indonesia}

Profitabilitas , solvabilitas dan likuiditas secara simultan tidak berpengaruh signifikan terhadap harga saham. Hal ini dapat terlihat pada nilai signifikansi sebesar 0,328 >0,05 dan nilai $F_{\text {hitung }}$ sebesar 1,180 yang lebih kecil dari nilai $\mathrm{F}_{\text {tabel }}$ sebesar 2,80.

Profitabilitas, solvabilitas dan likuiditas merupakan rasio keuangan yang digunakan untuk menilai kinerja keuangan suatu perusahaan selama periode tertentu. Profitabilitas merupakan rasio keuangan yang digunakan untuk melihat kemampuan perusahaan dalam memperoleh laba, jika semakin tinggi profitabilitas makan semakin baik. Solvabilitas merupakan rasio keuangan untuk mengukur seberapa besar tingkat jaminan modal sendiri dalam menjamin keseluruhan kewajiban yang dimiliki. Perusahaan yang solvabel adalah perusahaan yang memiliki utang tidak melebihi dari total aset yang dimiliki atau memiliki tingkat solvabilitas yang rendah. Likuiditas adalah rasio keuangan untuk mengetahui kemampuan perusahaan dalam memenuhi kewajiban jangka pendek yang telah jatuh tempo. Profitabilitas dan likuiditas mengalami penurunan dan solvabilitas mengalami kenaikan sehingga memengaruhi minat investor atau calon investor untuk melakukan investasi pada perusahaan yang berdampak harga saham yang tidak mengalami kenaikan. 


\section{KESIMPULAN}

Kesimpulan dari penelitian yang dilakukan antara lain.

1. Profitabilitas (Net Profit Margin) tidak terdapat pengaruh yang signifikan terhadap harga saham pada nilai signifikansi sebesar $0,100>0,05$ dan $\mathrm{T}_{\text {hitung }}<\mathrm{T}_{\text {tabel }}$ dengan angka sebesar $-1,677<2,01290$.

2. Solvabilitas (Debt to Equity Ratio) tidak terdapat pengaruh yang signifikan terhadap harga saham pada nilai signifikansi sebesar 0,735>0,05 dan $\mathrm{T}_{\text {hitung }}<\mathrm{T}_{\text {tabel }}$ dengan angka sebesar $0,340<2,01290$.

3. Likuiditas (Current Ratio) tidak terdapat pengaruh yang signifikan terhadap harga saham pada nilai signifikansi sebesar 0,622 $>0,05$ dan $\mathrm{T}_{\text {hitung }}<\mathrm{T}_{\text {tabel }}$ dengan angka sebesar $0,497<2,01290$.

4. Profitabilitas (Net Profit Margin), Solvabilitas (Debt to Equity Ratio), dan Likuiditas (Current Ratio) secara simultan tidak berpengaruh terhadap harga saham pada nilai signifikansi 0,328 $>0,05$ dan $\mathrm{T}_{\text {hitung }}<\mathrm{T}_{\text {tabel }}$ yaitu $1,180<2,80$.

5. Nilai koefisien determinasi sebesar $7,1 \%$ yang mengartikan bahwa harga saham dapat dijelaskan oleh variabel Profitabilitas (Net Profit Margin), Solvabilitas (Debt to Equity Ratio), dan Likuiditas (Current Ratio) sedangkan sisanya sebesar 92,9\% dijelaskan oleh variabel lain yang tidak jelaskan dalam penelitian ini.

Berdasarkan penelitian yang dilakukan, terdapat beberapa saran yang dapat diberikan antara lain.

1. Pada penelitian yang akan dilakukan selanjutnya supaya bisa mengganti variabel independen lain yang dapat mempengaruhi harga saham selain dari variabel independen yang digunakan peneliti dalam penelitian ini yaitu Profitabilitas (Net Profit Margin), Solvabilitas (Debt to Equity Ratio), dan Likuiditas (Current Ratio). Hal ini bertujuan agar penelitian dapat dijadikan sebagai salah satu refenrensi yang bermanfaat untuk masa yang akan datang.

2. Pada penelitan yang dilakukan oleh peneliti, data-data yang digunakan hanya perusahaan yang terdaftar dalam indeks IDX30 yang terdaftar di Bursa Efek Indonesia periode 20162020. Peneliti berharap untuk penelitian dimasa yang akan datang dapat memperbanyak sampel dan menambah periode waktu penelitian sehingga sampel yang diperoleh lebih banyak.

3. Hasil dari penelitian ini dapat dijadikan sebagai referensi untuk penelitian selanjutnya, terkhusus untuk penelitian yang menggunakan variabel independen Profitabilitas (Net Profit Margin), Solvabilitas (Debt to Equity Ratio), dan Likuiditas (Current Ratio).

\section{DAFTAR PUSTAKA}

Cahyanti, D. A., Nuraina, E., \& Wijaya, A. L. (2017). Pengaruh Likuiditas, Profitabilitas, dan Leverage Terhadap Arus Kas Masa Mendatang Pada Perusahaan Properti dan Real Estate di BEI. Assets: Jurnal Akuntansi Dan Pendidikan, 6(1), 26. https://doi.org/10.25273/jap.v6i1.1291

Hartono. (2017). Konsep Analisa Laporan Keuangan dengan Pendekatan Rasio \& SPSS. Yogyakarta: Penerbit Deepublish.

Mahulae, D. Y. D. (2020). Analisis Pengaruh Efisiensi Modal Kerja, Likuiditas, Dan Solvabilitas Terhadap Profitabilitas. JUMANSI STINDO, 2.

Sanjaya, S., \& Rizky, F. (2018). Analisis Profitabilitas Dalam Menilai Kinerja Keuangan Pada PT. Taspen (Persero) Medan. KITABAH, 2.

Saputra, R., \& Syarfan, L. O. (2017). Analisis Kinerja Keuangan Pada Koperasi Tirta Dharma Perusahaan Daerah Air Minum Kota Pekanbaru. Jurnal Valuta, 3. 
Tewal, B., \& Jan, A. B. H. (2017). Pengaruh Current Ratio, Der, Roa Dan Npm Terhadap Harga Saham Pada Perusahaan Food and Beverages Yang Terdaftar Di Bei (Periode 2013-2015). Jurnal Riset Ekonomi, Manajemen, Bisnis Dan Akuntansi, 5(2), 1813-1822. https://doi.org/10.35794/emba.v5i2.16399

Tiaras, I., \& Wijaya, H. (2017). Pengaruh Likuiditas, Leverage, Manajemen Laba, Komisaris Independen Dan Ukuran Perusahaan Terhadap Agresivitas Pajak. Jurnal Akuntansi, 19(3), 380. https://doi.org/10.24912/ja.v19i3.87

Tobing, V. C. L., \& Sitinjak, S. S. B. (2020). Pengaruh Current Ratio Dan Net Profit Margin Terhadap Harga Saham Di Perusahan Bursa Efek Indonesia. Jurnal AKRAB JUARA, 5(3), 161-174. 